\title{
CHRONIC HEPATITIS C VIRUS INFECTIONS IN BRAZILIAN PATIENTS: ASSOCIATION WITH GENOTYPES, CLINICAL PARAMETERS AND RESPONSE TO LONG TERM ALPHA INTERFERON THERAPY
}

Leda BASSIT(1,2), Luiz C. DA SILVA(1,3), Gabriela RIBEIRO-DOS-SANTOS(1,2), Geert MAERTENS(4), Flair J. CARRILHO(1,3), Luis E.P. FONSECA(1,3), Venâncio A.F. ALVES(1), Luis C.C. GAYOTTO(1), Analice N. PEREIRA(2), Kioko TAKEI(1), Dalton CHAMONE(1,2) \& Amadeo SÁEZ-ALQUÉZAR(1)

\begin{abstract}
SUMMARY
The present study assessed the clinical significance of hepatitis $\mathrm{C}$ virus (HCV) genotypes and their influence on response to long term recombinant-interferon-alpha $(\mathrm{r}-\mathrm{IFN}-\alpha)$ therapy in Brazilian patients. One hundred and thirty samples from patients previously genotyped for the $\mathrm{HCV}$ and with histologically confirmed chronic hepatitis $\mathrm{C}(\mathrm{CH}-\mathrm{C})$ were evaluated for clinical and epidemiological parameters (sex, age, time of HCV infection and transmission routes). No difference in disease activity, sex, age or mode and time of transmission were seen among patients infected with HCV types 1, 2 or 3. One hundred and thirteen of them were treated with 3 million units of r-IFN- $\alpha, 3$ times a week for 12 months. Initial response (IR) was significantly better in patients with genotype 2 $(100 \%)$ and $3(46 \%)$ infections than in patients with genotype $1(29 \%)(\mathrm{p}<0.005)$. Among subtypes, difference in IR was observed between $1 \mathrm{~b}$ and 2 ( $\mathrm{p}<0.005)$, and between $1 \mathrm{~b}$ and $3 \mathrm{a}(\mathrm{p}<0.05)$. Sustained response (SR) was observed in $12 \%$ for (sub)type $1 \mathrm{a}$, $13 \%$ for $1 b, 19 \%$ for $3 a$, and $40 \%$ for type 2 ; significant differences were found between $1 \mathrm{~b}$ and 2 (p < 0.001 ), and between $1 \mathrm{~b}$ and $3 a(p<0.05)$. Moreover, presence of cirrhosis was significantly associated with non response and response with relapse ( $<<0.05)$. In conclusion, non-1 HCV genotype and lack of histological diagnosis of cirrhosis were the only baseline features associated with sustained response to treatment. These data indicate that HCV genotyping may have prognostic relevance in the responsiveness to $\mathrm{r}-\mathrm{IFN}-\alpha$ therapy in Brazilian patients with chronic HCV infection, as seen in other reports worldwide.
\end{abstract}

KEYWORDS: Brazilian patients; Genotypes; HCV; IFN therapy; Sustained response.

\section{INTRODUCTION}

Hepatitis $\mathrm{C}$ virus (HCV) is the main etiologic agent of post-transfusion and sporadic non-A non-B hepatitis worldwide ${ }^{1,20}$. Chronic hepatitis $\mathrm{C}$ occurs in at least $85 \%$ of patients with acute $\mathrm{HCV}$ infection, and cirrhosis develops in $20-30 \%$ of these individuals ${ }^{12,20,34,40}$.

The HCV genome is a positive-stranded RNA molecule of $\sim 10 \mathrm{~kb}$ and is highly variable $e^{6,8,9}$. Some regions of the viral genome, such as 5, non-coding (NC) and core regions are rather conserved, while the envelope (E1 and E2) and the non-structural (NS) 5A regions exhibit marked variability. At present, 11 major types and at least 80 (sub)types can be differentiated according to the classification based upon various genetic analysis procedures ${ }^{24}$. The distribution of different HCV genotypes varies according to the geographic region and seems to be related to their time of divergence (500-2000 years ago) ${ }^{35}$. In South America, Europe, the United States and Japan, HCV genotypes 1, 2 and 3 account for the majority of the infections, being (sub)type $1 \mathrm{~b}$ the most preva-

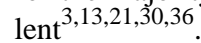

Several studies in European, Asian and North American patients have shown that epidemiological parameters such as age, risk factors and duration of infection may be associated with HCV genotypes. Analyses of HCV transmission routes have shown that infections by (sub)types $1 \mathrm{a}$ and $3 \mathrm{a}$ are associated with intravenous drug abuse (IVDA), while $1 \mathrm{~b}$ infections are predominant in post-transfusion hepatitis $\mathrm{C}^{13,21,29}$.

Evidences from recent studies conducted in Europe and Japan suggest that some HCV genotypes, especially (sub)type $1 \mathrm{~b}$, lead to a more severe course of viral infection and appear to be associated with distinct manifestations of the disease ${ }^{5,26,39}$. Despite these findings, there have been other reports suggesting that HCV genotypes do not have a significant effect on the severity and outcome of liver disease $e^{4,21}$.

(1) Pharmaceutical Sciences and Medical Schools of the University of São Paulo, SP, Brazil.

(2) Fundação Pró-Sangue Hemocentro de São Paulo (FPS/HSP), SP, Brazil.

(3) Tropical Medicine Institute, São Paulo, SP, Brazil.

(4) Innogenetics NV Gent, Belgium.

Correspondence to: Leda Bassit, M.Sc., Fundação Pró-Sangue Hemocentro de São Paulo (FPS/HSP), Av. Dr. Enéas de Carvalho Aguiar 155 - PAMB 1º Andar, Bloco 4, 05403-000 São Paulo, SP, Brasil Tel. +55-11-3061 5544, Ext. 229/221/338, Fax +55-11-280 8317. e-mail. Lbassit@ dialdata.com.br 


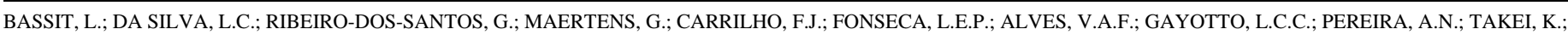
CHAMONE, D. \& SÁEZ-ALQUÉZAR, A. - Chronic hepatitis C virus infections in Brazilian patients: association with genotypes, clinical parameters and response to long term alpha interferon therapy. Rev. Inst. Med. trop. S. Paulo, 41(3): 183-189, 1999.

The current standard interferon (IFN) therapy with 3 million units (MU) three times a week, administered for 6 months, is associated with sustained response (SR) in about $10-20 \%$ of patients ${ }^{28}$. This rate can be increased by $10-15 \%$ using higher doses or longer duration of therapy ${ }^{16,31}$. Combinations of IFN with Ribavirin seem to significantly increase the SR rate in patients with chronic hepatitis $\mathrm{C}^{7}$.

The efficacy of interferon therapy differs among the various genotypes, with genotype $1 \mathrm{~b}$ emerging as an important predictive factor of non-response ${ }^{17,28,41}$. In Brazil, the relationship between HCV genotypes and response to treatment is not well established. We therefore assessed whether HCV genotyping is associated with clinical characteristics and response to long-term recombinant-interferon-alpha ( $r-$ IFN- $\alpha$ ) treatment in 130 Brazilian patients with chronic HCV infection.

\section{MATERIAL AND METHODS}

\section{Patients}

We studied 130 consecutive Brazilian patients with chronic hepatitis C between 1994 and 1997 from the Department of Gastroenterology, University of São Paulo. The diagnosis was based on (i) elevated alanine aminotransferase (ALT) levels - higher than 1.5-fold the upper limit of the normal range -, (ii) liver biopsy, (iii) presence of anti-HCV antibodies in serum - determined by the ELISA INNOTEST HCV Ab III, Innogenetics, Belgium and confirmed by the Immunoblot test INNOLIA HCV Ab III, Innogenetics or RIBA-2, Ortho Diagnostics, Raritan, NJ, USA - and (iv) HCV-RNA (determined by PCR). Of these, 88 (68\%) patients were born in São Paulo state and, of other 42 patients, 19 (14\%) were from other regions of Brazil and have been living in São Paulo state. The origin of the remaining 23 patients could not be well defined. The patients were aged between 11 and 75 years, with a mean age of 47 years; $83(64 \%)$ were males and $47(36 \%)$, females.

Fifty $(38.5 \%)$ out of 130 patients had previously been transfused with blood products, $15(11.5 \%)$ had a history of intravenous drug abuse, and $11(8.5 \%)$ had undergone major surgical procedures. The remaining 54 patients $(41.5 \%)$ had no known risk factors.

The time of HCV infection was considered to be the date of blood transfusion for the 47 out of 50 patients with a history of transfusion with blood products. Data from the remaining three were not available.

Among these 130, there was no patient with hepatitis B virus antigenemia, IgM anti-HAV-positivity, cytomegalovirus, Epstein-Barr virus, alcoholism, autoimmune hepatitis, primary biliary cirrhosis, primary sclerosing cholangitis or with a history of treatment with hepatotoxic drugs.

Seventeen patients were withdrawn from treatment: one was under 18 years of age, two were older than 70 years, and 14 had early side effects. Interferon therapy was administered to 113 patients who showed a positive result in the HCV-PCR just before starting the r-IFN- $\alpha$ therapy. Doses of three MU were taken 3 times weekly for 12 months.

All patients gave informed consent for the study, which was approved by the local ethics committee.

\section{Liver Histology}

Patients were separated into two groups: patients with chronic hepatitis and patients with liver cirrhosis. Liver biopsy specimens were available for 124 of the 130 patients: 48 (38.7\%) with histological diagnosis of liver cirrhosis and $76(61.3 \%)$ with chronic hepatitis, the remaining 6 could not undergo such a diagnosis due to blood coagulation disturbances.

Liver biopsy specimens were assessed according to international criteria $^{11}$ and histopathology will be submitted for publication elsewhere.

\section{Response to Interferon Therapy}

All patients were evaluated before therapy, at the end of the treatment period and 6 months later.

Based on ALT activity and HCV-RNA detection in serum, three categories were used to define response: (i) sustained response (SR) normal serum ALT levels and negative HCV-RNA at the $6^{\text {th }}$ month after treatment (response was also considered in case of abnormal ALT levels with negative HCV-RNA); (ii) response with relapse (RR) - normal ALT levels and negative HCV-RNA at the end of therapy but with abnormal values during follow-up; and (iii) non response (NR) - abnormal ALT levels with positive HCV-RNA at the end of therapy.

\section{Detection of HCV RNA}

For HCV RNA detection, whole blood was collected prior to treatment, at the end of treatment and after 6 months of follow-up. Serum samples were prepared within 4 hours after sampling; aliquots were stored at $-20{ }^{\circ} \mathrm{C}$.

In all 130 patients, serum samples were tested for HCV RNA with the use of nested reverse-transcription polymerase chain reaction (RTPCR) targeted to the 5' non-coding region and/or Amplicor HCV (Roche Molecular Systems, Somerville, NJ). The detection limit of these assays is around $1000 \mathrm{HCV}$ RNA copies per milliliter of serum ${ }^{10}$.

\section{HCV genotyping}

The genotyping was performed by a reverse hybridization assay, the Line Probe Assay (INNO-LiPA HCV or INNO-LiPA HCV II -second generation-, Innogenetics, Belgium), based on hybridization of labeled PCR amplification products to specific probes directed against the variable regions of the 5 , NCR of the various genotypes ${ }^{36,37}$. The genotyping results are from another study of ours ${ }^{3}$.

\section{Statistical Analysis}

Percentage data were compared with Fisher's exact test, FisherFreeman-Halton test and Likelihood ratio test as appropriate. Distribution of continuous variables was analyzed by the Mann-Whitney U test for two groups (i.e., the mean age between no cirrhosis and cirrhosis groups), or the Kruskal-Wallis test for three groups (i.e., the mean age between genotypes 1,2 and 3$)^{2,14}$. A probability (p) value of $<0.05$ was considered statistically significant. 


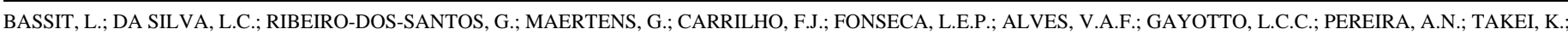
CHAMONE, D. \& SÁEZ-ALQUÉZAR, A. - Chronic hepatitis C virus infections in Brazilian patients: association with genotypes, clinical parameters and response to long term alpha interferon therapy. Rev. Inst. Med. trop. S. Paulo, 41(3): 183-189, 1999.

\section{RESULTS}

Clinical characteristics and liver biopsy of patients infected with different Hepatitis $\mathrm{C}$ virus genotypes

We compared all of the (sub)types within the major genotypes to clinical and biopsy data. No differences were seen in sex, age, epidemiological risk and liver histology among the (sub)types within each major type. Therefore, the same comparison was carried out in relation to the major types. The HCV genotypes prevalence and distribution are shown in Table 1.

No difference in sex ratio $(\mathrm{p}=0.20$; Table 2$)$ and mean age $(\mathrm{p}=$ 0.57 ; Table 2) was seen among the 130 patients infected within the various HCV genotypes. However, when comparing (sub)type 1a with the other (sub)types, patients infected with (sub)type 1a (mean age $=42$ ) were younger than patients infected with the other (sub)types (mean age $=50)(\mathrm{p}=0.03)$.

Of the 47 patients, in which the estimated duration of $\mathrm{HCV}$ infection was documented, no difference with this regard was seen among genotypes 1, 2 and 3, suggesting that the distribution of HCV infecting strains has not changed substantially over the period during which our patients acquired HCV (1 to 35 years). Additionally, the duration of infection did not differ between patients with cirrhosis and with chronic hepatitis $(\mathrm{p}=0.45)$.

Risk factors for the acquisition of hepatitis $\mathrm{C}$ fell into four groups: blood transfusion (38\%), previous intravenous drug use (12\%), surgical history with unknown administration of blood products $(9 \%)$ and spo- radic or unknown causes $(41 \%)$. We found no differences with respect to these features in patients infected with HCV genotypes 1, 2 and 3 $(\mathrm{p}=0.36)$. Similarly, we found no association among HCV genotypes and the patients who had acquired HCV through blood-products transfusion compared with those who had been infected by other routes.

\section{Table 1}

Distribution of genotypes in 130 Brazilian patients with chronic hepatitis C.

\begin{tabular}{lccc}
\hline $\begin{array}{l}\text { Type } \\
\text { [no. of isolates / \%] }\end{array}$ & $\begin{array}{c}\text { HCV } \\
\text { (sub)type }\end{array}$ & $\begin{array}{c}\text { No. patients } \\
130\end{array}$ & $\%$ \\
\hline & $1 \mathrm{a}$ & 28 & 21.5 \\
Type 1 (80 / 61.5) & $1 \mathrm{~b}$ & 44 & 33.8 \\
& 1 & 4 & 3.1 \\
& $1 *$ & 4 & 3.1 \\
\hline & $2 \mathrm{a}$ & 3 & 2.3 \\
Type 2 (7 / 5.4) & $2 \mathrm{~b}$ & 3 & 2.3 \\
& $2 \mathrm{a}+2 \mathrm{~b}$ & 1 & 0.8 \\
\hline & $3 \mathrm{a}$ & 40 & 30.8 \\
Type 3 (43 / 33.1) & $3 *$ & 3 & 2.3 \\
\hline
\end{tabular}

Genotyping of the PCR products of 123 (95\%) out of 130 samples were performed by the Line Probe Assay (INNO-LiPA HCV or INNO-LiPA HCV II -second generation-, Innogenetics); the remaining 7 were tested by a *serotyping assay (HCV Serotyping Assay 1-6, Murex Diagnostics, Dartford, UK) at the cessation of treatment (data from another study of ours $)^{3}$.

Table 2

Epidemiological and clinical data according to HCV genotypes

\begin{tabular}{|c|c|c|c|c|}
\hline Variable & $\begin{array}{c}\text { HCV Type } 1 \\
\mathrm{n}=80\end{array}$ & $\begin{array}{c}\text { HCV Type } 2 \\
n=7\end{array}$ & $\begin{array}{c}\text { HCV Type } 3 \\
n=43\end{array}$ & $\begin{array}{c}\text { Total } \\
\mathrm{n}=130\end{array}$ \\
\hline Sex (female/male) $n^{*}$ & $33 / 47$ & $3 / 4$ & $11 / 32$ & $47 / 83$ \\
\hline Mean age $\pm \mathrm{SD}, \mathrm{y}^{\phi}$ & $47 \pm 15.1$ & $50 \pm 10.4$ & $45 \pm 12.1$ & $46 \pm 13.9$ \\
\hline $\begin{array}{l}\text { Median duration of } \mathrm{HCV} \\
\text { infection (range) y, }{ }^{\Psi_{*}}\end{array}$ & $16(1-35)$ & $16(15-16)$ & $12(1-34)$ & $15(1-35)$ \\
\hline \multicolumn{5}{|l|}{ Epidemiologic risk, $\mathrm{n}(\%)^{*}$} \\
\hline Blood transfusion & $34(42)$ & $3(43)$ & $13(30)$ & $50(38)$ \\
\hline Intravenous drug use & $6(8)$ & $1(14)$ & $8(19)$ & $15(12)$ \\
\hline Surgery & $8(10)$ & $1(14)$ & $2(15)$ & $11(9)$ \\
\hline Unknown & $32(40)$ & $2(29)$ & $20(46)$ & $54(41)$ \\
\hline $\begin{array}{l}\text { Patients with cirrhosis / } \\
\text { number of patients assessed } \\
\text { for biopsy, } \mathrm{n} / \mathrm{n}(\%)^{*}\end{array}$ & 28/77 (36) & $1 / 7(14)$ & $19 / 40(48)$ & 48/124 (39) \\
\hline
\end{tabular}

$\mathrm{n}=$ number of patients,

*not statistically different,

$\mathrm{y}=$ years,

${ }^{\phi}$ no difference among the three major types (1,2 and 3); patients with subtype 1a were younger than the others $(\mathrm{p}=0.03)$,

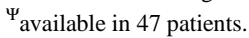




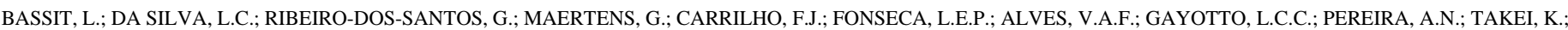
CHAMONE, D. \& SÁEZ-ALQUÉZAR, A. - Chronic hepatitis C virus infections in Brazilian patients: association with genotypes, clinical parameters and response to long term alpha interferon therapy. Rev. Inst. Med. trop. S. Paulo, 41(3): 183-189, 1999.

Of the 124 patients, infected with different $\mathrm{HCV}$ genotypes and from whom liver biopsy specimens were available, no significant difference was found regarding the presence or absence of cirrhosis ( $p=0.22$; Table 2 ). On the other hand, analysis of the presence of cirrhosis was significantly associated with older age $(\mathrm{p}<0.001)$; the mean age in patients with and without cirrhosis was 52 and 43 years, respectively.

\section{Responses to recombinant-Interferon-Alpha $(\mathrm{r}-\mathrm{IFN}-\alpha)$ therapy}

Forty four (39\%) out of 113 r-IFN- $\alpha$ treated patients were responders - 20 with sustained response (SR) and 24 with relapsed response (RR). The remaining 69(61\%) patients did not respond to treatment (non response). There was no significant interference of sex, mean age, and mode of acquisition in the response to treatment. However, a trend to a more favorable response was observed in patients without cirrhosis ( $p=0.06$, Table 3 ). Furthermore, when patients with a RR and those with NR were considered as a single group, a lower frequency of response was observed in patients with cirrhosis $(\mathrm{p}<0.05)$. The analysis of genotype distribution and response to therapy of the 113 patients, shown in Tables 3 and 4 , revealed significant differences $(\mathrm{p}<0.005)$.

Analysis of (sub)types among patients with response to r-IFN- $\alpha$ therapy (108 of 113 patients) is shown in Table 4. Patients infected with (sub)type 1a showed more often response to therapy $(n=9.36 \%)$ than patients infected with (sub)type $1 \mathrm{~b}(\mathrm{n}=8.21 \%)$. However, a higher frequency of response with relapse was found in the (sub)type 1a group (Table 4). Furthermore, a SR occurred less frequently in patients with

\section{Table 4}

Hepatitis C virus (sub)types* of sustained responders (SR), relapse responders (RR) and non responders (NR) to r-IFN- $\alpha$ treatment

\begin{tabular}{lrrr}
\hline \multirow{2}{*}{ Patients } & \multicolumn{2}{c}{$\mathrm{IR}^{\Psi}$} & NR \\
\cline { 2 - 3 } $\begin{array}{l}\text { HCV } \\
\text { (sub)types }\end{array}$ & \multicolumn{1}{c}{$\mathrm{SR}$} & \multicolumn{1}{c}{$\mathrm{RR}$} & \\
\hline $1 \mathrm{n}(\mathrm{n}=25)$ & $\mathrm{n}(\%)$ & $\mathrm{n}(\%)$ \\
$1 \mathrm{~b}(\mathrm{n}=39)$ & $3(12)$ & $6(24)$ & $16(64)$ \\
$2 \mathrm{a}, 2 \mathrm{~b}$ or $2 \mathrm{a}+2 \mathrm{~b}(\mathrm{n}=7)$ & $3(40)$ & $4(60)$ & $31(79)$ \\
$3 \mathrm{a}(\mathrm{n}=37)$ & $7(19)$ & $10(27)$ & $20(54)$ \\
Total $(\mathrm{n}=108)$ & $18(17)$ & $23(21)$ & $67(62)$ \\
\hline
\end{tabular}

*Available for 108 out of 113 patients; ${ }^{\Psi} \mathrm{IR}=$ initial responders.

Likelihood ratio test for: (sub)type 1a versus $1 \mathrm{~b}(\mathrm{p}>0.05)$; (sub)type $1 \mathrm{~b} v s$. type 2 ( $\mathrm{p}<0.001$ ); (sub)type $1 \mathrm{~b} v s .3 \mathrm{a}(\mathrm{p}<0.05)$.

(sub)type $1 \mathrm{~b}(13 \%)$ than was the case for type $2(40 \%)(\mathrm{p}<0.001)$ and type $3(19 \%)(\mathrm{p}<0.05)$.

\section{DISCUSSION}

As far as epidemiological data are concerned - sex, age, mode of acquisition and duration of infection - there was no difference among patients infected with HCV types 1,2 and 3. According to some studies, $\mathrm{HCV}$ (sub)type 1a is more frequently found in IVDA group. The

Table 3

Clinical, virological and histological parameters associated with biochemical and virological response in 113 Brazilian patients

\begin{tabular}{|c|c|c|c|c|}
\hline Variable & $\begin{array}{c}\text { SR } \\
\mathrm{n}(\%)\end{array}$ & $\begin{array}{c}\mathrm{RR} \\
\mathrm{n}(\%)\end{array}$ & $\begin{array}{c}\text { NR } \\
\mathrm{n}(\%)\end{array}$ & $\mathrm{p}$ value \\
\hline $\begin{array}{l}\text { Sex } \\
\quad \text { Male }(\mathrm{n}=72) \\
\text { Female }(\mathrm{n}=41)\end{array}$ & $\begin{array}{r}12(17) \\
8(20) \\
\end{array}$ & $\begin{array}{l}14(19) \\
10(24)\end{array}$ & $\begin{array}{l}46(64) \\
23(56)\end{array}$ & NS \\
\hline Mean age (years) & 47 & 51 & 46 & NS \\
\hline $\begin{array}{l}\text { Route of transmission } \\
\text { Blood transfusion }(\mathrm{n}=45) \\
\text { IVDA }(\mathrm{n}=12) \\
\text { Surgery }(\mathrm{n}=9) \\
\text { Sporadic }(\mathrm{n}=47) \\
\end{array}$ & $\begin{array}{l}6(13) \\
3(25) \\
2(22) \\
9(19) \\
\end{array}$ & $\begin{array}{r}12(27) \\
1(8) \\
1(11) \\
10(21) \\
\end{array}$ & $\begin{array}{r}27(60) \\
8(67) \\
6(67) \\
28(60) \\
\end{array}$ & NS \\
\hline Time of infection (median, y) & 22 & 12 & 16 & NS \\
\hline $\begin{array}{l}\text { Cirrhosis } \\
\text { Absent }(n=67) \\
\text { Present }(n=43)\end{array}$ & $\begin{array}{r}16(24) \\
3(7) \\
\end{array}$ & $\begin{array}{l}14(21) \\
10(23)\end{array}$ & $\begin{array}{l}37(55) \\
30(70)\end{array}$ & $\mathrm{p}=0.06$ \\
\hline $\begin{array}{l}\text { HCV genotype } \\
\text { Type } 1(\mathrm{n}=69) \\
\text { Type } 2(\mathrm{n}=7) \\
\text { Type } 3(\mathrm{n}=37)\end{array}$ & $\begin{array}{r}10(14.5) \\
3(43) \\
7(19) \\
\end{array}$ & $\begin{array}{r}10(14.5) \\
4(57) \\
10(27) \\
\end{array}$ & $\begin{array}{r}49(71) \\
0 \\
20(54) \\
\end{array}$ & $\mathrm{p}<0.005$ \\
\hline
\end{tabular}

Abbreviations: SR, sustained response; RR, response with relapse; NR, non response; NS, not significant ( $p>0.05$ ); n, number of patients; IVDA, intravenous drug abuser; y, year. 


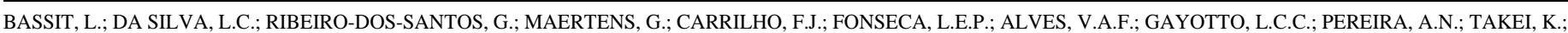
CHAMONE, D. \& SÁEZ-ALQUÉZAR, A. - Chronic hepatitis C virus infections in Brazilian patients: association with genotypes, clinical parameters and response to long term alpha interferon therapy. Rev. Inst. Med. trop. S. Paulo, 41(3): 183-189, 1999.

proportion of such a risk group was rather low (12\%) in our studied population, what may explain the lower frequency of (sub)type 1a as compared to other populations ${ }^{13}$. Nonetheless, the frequency of IVDA was evenly distributed among the three HCV types.

It is worth noting that we found no differences in the duration of $\mathrm{HCV}$ infection among genotypes 1, 2 and 3, in contrast to data from PAWLOTSKY and collaborators ${ }^{29}$, who found that patients infected with genotype 3 had a shorter infection than patients with genotype 1 . Thus, the former genotype may have been introduced into Europe more recently than the latter, but this does not seem to be our case.

The frequency of liver cirrhosis did not differ among the three genotypes, although the low number of patients infected with genotype 2 does not allow a definite conclusion. Discordant results are found in the literature; some authors have found no significant effect of HCV genotypes on the severity and outcome of liver disease ${ }^{4,21}$, whereas others have shown a relationship between $\mathrm{HCV}$ type $1 \mathrm{~b}$ infection and degree of fibrosis ${ }^{26}$.

In regard with age, we did find an association between presence of cirrhosis and older patients, as in accordance with other investigators $19,27,38$

When clinical, virological and histological parameters were compared with response to interferon therapy, no association was found between sustained response and young age or gender. Only HCV genotyping and a histological diagnosis of cirrhosis emerged as important predictive factors. A better SR in patients without cirrhosis was observed by us ( $\mathrm{p}<0.05$ ), as so by other authors ${ }^{15,25}$. Patients infected with genotype 2 presented a better sustained response rate than the others (Table 3). Furthermore, a better biochemical and virological initial response was observed in patients with genotypes 1a, 2 and $3 \mathrm{a}$ as compared with genotype $1 \mathrm{~b}$ (Table 4 ), which is in accordance with other reports ${ }^{17,22,41}$. The low rate of SR in patients with (sub)types $1 \mathrm{a}$ and $1 \mathrm{~b}$ infections has led some authors to suggest different therapeutic schedules, such as, higher dose of interferon or its association with Ribavirin $^{31,32,33}$.

Although SR in (sub)types 1a and $1 \mathrm{~b}$ infections was similar, the ratio of initial response was higher for patients infected with the former (sub)type: $36 \%$ and $21 \%$, respectively. These results were also obtained by LINDSAY and collaborators ${ }^{23}$, who observed a trend for patients with (sub)type 1a to respond better to higher doses of IFN. Therefore, higher doses of IFN and or combined treatment with Ribavirin may provide a means to prevent the degree of relapse and increase the overall SR rate of subtype $1 \mathrm{a}$.

Our analysis of response to r-IFN- $\alpha$ therapy showed that 20 out of $113(18 \%)$ patients had a SR. Similar results were recently documented in a study of patients treated with the standard schedule of $3 \mathrm{MU}$ of IFN thrice weekly for 6 months ${ }^{25}$. Nevertheless, according to the same authors, sustained response ranged from $29 \%$ to $22 \%$ when given for duration of 12 and 18 months, respectively ${ }^{18,31}$. This poor response rate - confirmed in our study with a large group of patients also submitted to a long term therapy - suggests that other schedules of therapy, such as initial daily doses of IFN or combination of IFN and Ribavirin, should be tried.

In conclusion, no difference according to sex, age, or mode of transmission were seen among patients infected with HCV types 1,2 or 3. Moreover, a better sustained response was observed in patients with genotypes 2 and $3 a$.

\section{RESUMO}

Hepatite C crônica em São Paulo, Brasil: associação entre genótipos do VHC, aspectos clínicos, epidemiológicos e resposta terapêutica

No presente estudo, avaliamos a importância clínicoepidemiológica da genotipagem do VHC em 130 pacientes com diagnóstico histológico de hepatite crônica $\mathrm{C}$ e sua influência na resposta terapêutica sustentada. Não se observou associação entre os genótipos e os aspectos clínico-epidemiológicos como sexo, idade, vias de transmissão, presença ou não de cirrose e tempo de infecção. Dos 130 pacientes, 113 foram submetidos a tratamento com interferon- $\alpha$-recombinante durante um período médio de 12 meses. A resposta completa, avaliada pela viremia e dosagem da ALT no término do tratamento, foi significativamente melhor nos portadores dos genótipos $2(100 \%)$ e 3 (46\%) do que nos portadores do tipo 1 (29\%) ( $\mathrm{p}<0,005)$. Observou-se também diferença significativa quando se analisou a resposta completa entre os subtipos $1 b$ e $2(p<0,005)$ e $1 b$ e $3 a(p<0,05)$. A resposta sustentada (viremia negativa e/ou normalização da ALT ao sexto mês de monitoração pós tratamento) para os portadores dos genótipos 1a, 1b, 3 a e 2 foi de $12 \%, 13 \%, 19 \%$ e $40 \%$, respectivamente; houve diferença significativa entre os genótipos $1 \mathrm{~b}$ e $2(\mathrm{p}<0,001)$ e $1 \mathrm{~b}$ e $3 \mathrm{a}(\mathrm{p}<0,05)$. Além disso, observou-se associação entre presença de cirrose e não resposta e resposta com recaída $(\mathrm{p}<0,05)$. Portanto, o genótipo diferente de 1 e ausência de cirrose foram os únicos fatores que apresentaram associação à resposta terapêutica sustentada. Este estudo mostrou a importância da genotipagem na susceptibilidade ao tratamento da infecção crônica pelo VHC.

\section{ACKNOWLEDGMENTS}

The authors are grateful to Fred Shapiro (Innogenetics NV Gent, Belgium) for revising the paper, to Cristiane Murta Ramalho Nascimento, M.D., (Medical School São Paulo, Brazil) for her help in the statistical analysis, to Maria Cristina Sales (Fundação Pró-Sangue Hemocentro de São Paulo - Diagnostic Laboratory) for collecting the blood samples and to Bernhard Kleter, Ph.D., (Dept. of Molecular Biology - Delft Diagnostic Laboratory, the Netherlands) for useful suggestions and critical reading of the manuscript.

\section{REFERENCES}

1. ALTER, A.J.; PURCELL, R.H.; SHIH, J.W. et al. - Detection of antibody to hepatitis C virus in prospectively followed transfusion recipients with acute and chronic non-A non-B hepatitis. New Engl. J. Med., 321: 1494-1500, 1989.

2. ALTMAN, D.G. - Practical statistics for medical research. London, Chapman \& Hall, 1995. p.253-257. 


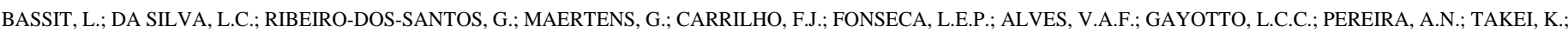
CHAMONE, D. \& SÁEZ-ALQUÉZAR, A. - Chronic hepatitis C virus infections in Brazilian patients: association with genotypes, clinical parameters and response to long term alpha interferon therapy. Rev. Inst. Med. trop. S. Paulo, 41(3): 183-189, 1999.

3. BASSIT, L.; RIBEIRO-DOS-SANTOS, G.; DA SILVA, L.C. et al. - Genotype distribution of hepatitis C virus in São Paulo, Brazil: rare subtype found. Hepatology, 29: 994-995, 1999

4. BENVEGNÙ, L.; PONTISSO, P.; CAVALLETTO, D. et al. - Lack of correlation between hepatitis $\mathrm{C}$ virus genotypes and clinical course of hepatitis $\mathrm{C}$ virus-related cirrhosis. Hepatology, 25: 211-215, 1997.

5. BRUNO, S.; SILINI, E.; CROSIGNANI, A. et al. - Hepatitis C virus genotypes and risk of hepatocellular carcinoma in cirrhosis: a prospective study. Hepatology, 25: 754-758, 1997.

6. CHAN, S.-W.; MCOMISH, F.; HOLMES, E.C. et al. - Analysis of a new hepatitis C virus type and its phylogenetic relationship to existing variants. J. gen. Virol., 73: 1131-1141, 1992.

7. CHEMEllo, L.; CAVAlLetTO, L.; BERNARDinEllo, E. et al. - The effect of interferon alfa and ribavirin combination therapy in naive patients with chronic hepatitis C. J. Hepat., 23 (suppl.): 8-12, 1995.

8. CHOO, Q.-L.; KUO, G.; WEINER, A.J. et al. - Isolation of a cDNA clone derived from a blood-borne non-A, non-B viral hepatitis genome. Science, 244: 359-362, 1989.

9. CHOO, Q.-L.; RICHMAN, K.H.; HAN, J.H. et al. - Genetic organization and diversity of the hepatitis C virus. Proc. nat. Acad. Sci. (Wash.), 88: 2451-2455, 1991.

10. DE MEDINA, M. \& SCHIFF, E.R. - Hepatitis C: diagnostic assays. Semin. Liver Dis., 15: 33-39, 1995.

11. DESMET, V.J.; GERBER, M.; HOOFNAGLE, J.H.; MANNS, M. \& SCHEUER, P.J. Classification of chronic hepatitis: diagnosis, grading and staging. Hepatology, 19: 1513-1520, 1994.

12. DI BISCEGLIE, A.M.; GOODMAN, Z.D.; ISHAK, K.G. et al. - Long-term clinical and histopathological follow-up of chronic posttransfusion hepatitis. Hepatology, 14: 969-974, 1991

13. FEUCHT, H.-H.; SCHRÖTER, M.; ZÖLLNER, B. et al. - The influence of age on the prevalence of hepatitis $C$ virus subtypes 1a and 1b. J. infect. Dis., 175: 685-688, 1997.

14. FLEISS, J.L. - Statistical methods for rates and proportions. 2.ed. New York, John Wiley, 1981. p.321.

15. GARSON, J.A.; BRILLANTI, S.; WHITBY, K. et al. - Analysis of clinical and virological factors associated with response to alpha interferon therapy in chronic hepatitis C. J. med. Virol., 45: 348-353, 1995.

16. HOOFNAGLE, J.H. \& DI BISCEGLIE, A.M. - The treatment of chronic viral hepatitis. New Engl. J. Med., 336: 347-356, 1997.

17. HOPF, U.; BERG, T.; KÖNIG, V. et al. - Treatment of chronic hepatitis C with interferon alpha: long-term follow-up and prognostic relevance of HCV genotypes. J. Hepat., 24 (suppl. 2): 67-73, 1996.

18. JOUËT, P.; ROUDOT-THORAVAL, F.; DHUMEAUX, D. \& METREAU, J.M. Comparative efficacy of interferon alpha in cirrhotic and noncirrhotic patients with non-A, non-B, C hepatitis. Gastroenterology, 106: 686-690, 1994.
19. KLETER, B.; BROUWER, J.T.; NEVENS, F. et al. - Hepatitis C virus genotypes: epidemiological and clinical associations. Liver, 18: 32-38, 1998.

20. KUO, G.; CHOO, Q.-L.; ALTER, H.J. et al. - An assay for circulating antibodies to a major etiologic virus of human non-A, non-B hepatitis. Science, 244: 362-364, 1989.

21. LAU, J.Y.N.; DAVIS, G.L.; PRESCOTT, L.E. et al. - Distribution of hepatitis C virus genotypes determined by line probe assay in patients with chronic hepatitis $\mathrm{C}$ seen at tertiary referral centers in the United States. Ann. intern. Med., 124: 868-876, 1996.

22. LE GUEN, B.; SQUADRITO, G.; NALPAS, B. et al. - Hepatitis C virus genome complexity correlates with response to interferon therapy: a study in French patients with chronic hepatitis C. Hepatology, 25: 1250-1257, 1997.

23. LINDSAY, K.L.; DAVIS, G.L.; SCHIFF, E.R. et al. - Response to higher doses of interferon alfa- $2 \mathrm{~b}$ in patients with chronic hepatitis $\mathrm{C}$ : a randomized multicenter trial. Hepatitis Interventional Therapy Group. Hepatology, 24: 1034-1040, 1996.

24. MAERTENS, G. \& STUYVER, L. - Genotypes and genetic variation of hepatitis C virus. In: HARRISON, T.J. \& ZUCKERMAN, A.J., ed. The molecular medicine of viral hepatitis. England, Wiley, 1997. p.183-233.

25. MARCELLIN, P.; BOYER, N.; MARTINOT, M. \& ERLINGER, S. - Interferon therapy in hepatitis C: benefits and limitations. In: ARROYO, V.; BOSCH, J.; BRUGUERA, M. \& RODÉS, J., ed. Therapy in liver diseases. The pathophysiological basis of therapy. Barcelona, A.S. Masson, 1997. p.309-316.

26. MIHM, S.; FAYYAZI, A.; HARTMANN, H. \& RAMADORI, G. - Analysis of histopathological manifestations of chronic hepatitis $\mathrm{C}$ virus infection with respect to virus genotype. Hepatology, 25: 735-739, 1997.

27. MITA, E.; HAYASHI, N.; KANAZAWA, Y. et al. - Hepatitis C virus genotype and RNA titer in the progression of type C chronic liver disease. J. Hepat., 21: 468-473, 1994

28. PAWLOTSKY, J.-M.; ROUDOT-THORAVAL, F.; BASTIE, A. et al. - Factors affecting treatment responses to interferon- $\alpha$ in chronic hepatitis C. J. infect. Dis.; 174: 1-7, 1996.

29. PAWLOTSKY, J.M.; TSAKIRIS, L.; ROUDOTTHORAVAL, F. et al. - Relationship between hepatitis $\mathrm{C}$ virus genotypes and sources of infection in patients with chronic hepatitis C. J. infect. Dis., 171: 1607-1610, 1995.

30. PEIG-GINABREDA, M.G.; YOSHIDA, C.F.T. \& NIEL, C. - Genomic characterization of Brazilian hepatitis $\mathrm{C}$ virus genotypes 1a and 1b. Braz. J. med. biol. Res., 30: 339-345, 1997.

31. POYNARD, T.; BEDOSSA, P.; CHEVALLIER, M. et al. - A comparison of three interferon alfa-2b regimens for the long-term treatment of chronic non-A, non-B hepatitis. New Eng. J. Med., 332: 1457-1462, 1995.

32. REICHARD, O.; NORKRANS, G.; FRYDEN, A. et al. - Randomized, double-blind, placebo-controlled trial of interferon alpha- $2 \mathrm{~b}$ with or without ribavirin for chronic hepatitis C. The Swedish study group. Lancet, 351: 83-87, 1998.

33. SCHALM, S.W.; BROUWER, J.T.; CHEMELLO, L. et al. - Interferon-ribavirin combination therapy for chronic hepatitis C. Dig. Dis. Sci., 41 (suppl.): 131S-134S, 1996 


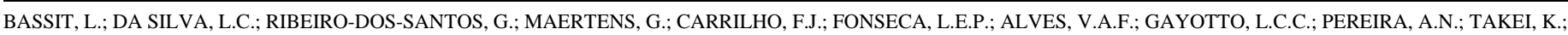
CHAMONE, D. \& SÁEZ-ALQUÉZAR, A. - Chronic hepatitis C virus infections in Brazilian patients: association with genotypes, clinical parameters and response to long term alpha interferon therapy. Rev. Inst. Med. trop. S. Paulo, 41(3): 183-189, 1999.

34. SHAKIL, A.O.; CONRY-CANTINELA, C.; ALTER, H.J. et al. - Volunteer blood donors with antibody to hepatitis $\mathrm{C}$ virus: clinical, biochemical, virologic, and histologic features. Ann. intern. Med., 123: 330-337, 1995.

35. SMITH, D.B.; PATHIRANA, S.; DAVIDSON, F. et al. - The origin of hepatitis C virus genotypes. J. gen. Virol., 78: 321-328, 1997.

36. STUYVER, L.; ROSSAU, R.; WYSEUR, A. et al. - Typing of hepatitis C virus isolates and characterization of new subtypes using a line probe assay. J. gen. Virol., 74: 1093-1102, 1993.

37. STUYVER, L.; WYSEUR, A.; VAN ARNHEM, W.; HERNANDEZ, F. \& MAERTENS, G. - Second-generation line probe assay for hepatitis $\mathrm{C}$ virus genotyping. J. clin. Microbiol., 34: 2259-2266, 1996.
38. YAMADA, M.; KAKUMU, S.; YOSHIOKA, K. et al. - Hepatitis C virus genotypes are not responsible for development of serious liver disease. Dig. Dis. Sci., 39: 234-239, 1994.

39. YOSHIOKA, K.; AIYAMA, T.; OKUMURA, A. et al. - Humoral immune response to the hypervariable region of hepatitis $\mathrm{C}$ virus differs between genotypes $1 \mathrm{~b}$ and $2 \mathrm{a}$. J. infect. Dis., 175: 505-510, 1997.

40. YUKI, N.; HAYASHI, N. \& KAMADA, T. - HCV viraemia and liver injury in symptom-free blood donors. Lancet, 342: 444, 1993.

41. ZEIN, N.N.; RAKELA, J.; KRAWITT, E.L. et al. - Hepatitis C virus genotypes in the United States: epidemiology, pathogenicity, and response to interferon therapy. Ann. intern. Med., 125: 634-639, 1996.

Received: 23 February 1999

Accepted: 25 April 1999 